\title{
FAKTOR YANG MEMPENGARUHI REKRUTMEN DOKTER DI PUSKESMAS WILAYAH KERJA DINAS KESEHATAN KABUPATEN BUOL TAHUN 2016
}

\author{
FACTORS AFFECTING RECRUITMENT OF PHYSICIANS AT PRIMARY HEALTH CARE IN THE \\ WORK AREA OF PUBLIC HEALTH OFFICE OF BUOL YEAR 2016
}

\author{
Arifandi ${ }^{1}$, Andreasta Meliala ${ }^{2}$ \\ ${ }^{1}$ Mahasiswa Pascasarjana IImu Kesehatan Masyarakat, \\ Fakultas Kedokteran Universitas Gadjah Mada, Yogyakarta \\ ${ }^{2}$ Departemen Kebijakan dan Manajemen Pelayanan Kesehatan \\ Fakultas Kedokteran Universitas Gadjah Mada, Yogyakarta
}

\begin{abstract}
Background: One of the health human resource management functions is to perform recruitments. Recruitment is a practice or activity undertaken by an organization with the primary purposes of identifying and attracting potential workers. Based on the profile data of Public Health Office of Buol by 2015 and 2016 were still lacking of physicians. This suggested that recruitment process conducted by Public Health Office of Buol was ineffective because it didn't meet the standard of supply. This study aims to determine procedures of physician's recruitment at Public Health Office of Buol and identify factors affecting the willingness of physicians to be placed at Primary Health Care of Buol. Method: This is descriptive study with qualitative approach. Informants collected were 11 respondents $(\mathrm{N}=11)$ consisting of Officers of Public Health Office, Regiona Employment Institution, Non-Permanent Physicians working in the District of Buol. Finding: The number of Primary Care Physicians has not met yet the standard of the need and the distribution is not widespread. Factors affecting the willingness of physicians to work in Buol are compensation which is accordance with the standard of salary for the very remote areas and the reward, career path in which physicians have the chance of being civil servants as well as further promotion of education. Inhibiting factors including working condition, workload and environmental factors such as quiet and remote area. Conclusion: Recruitment of physicians of Primary Health Care conducted by Public Health Office of Buol was ineffective yet and need improvement efforts regarding recruitment process and improves factors supporting the willingness of physicians to work in the District of Buol.
\end{abstract}

Keywords: recruitment, physician, supporting, inhibit.

\footnotetext{
ABSTRAK

Latar Belakang: Salah satu fungsi manajemen sumber daya manusia kesehatan adalah melaksanakan rekrutmen. Jumlah dokter di Kabupaten Buol masih kurang. Pada tahun 2015 jumlah dokter di Kabupaten Buol adalah sebanyak 15 dokter dengan rincian 9 dokter umum dan 6 dokter gigi, sedangkan standarnya adalah 26 dokter dengan rincian 15 dokter umum dan 11 dokter gigi. Oleh karena itu, ada kekurangan sebanyak 11 dokter dengan rincian 6 dokter umum dan 5 dokter gigi. Pada tahun 2016, jumlah dokter di Kabupaten Buol adalah sebanyak 8 dokter dengan rincian 3 dokter umum dan 5 dokter gigi, sedangkan standarnya adalah 26 dokter dengan
}

rincian 15 dokter umum dan 11 dokter gigi. Oleh karena itu, ada kekurangan sebanyak 18 dokter dengan rincian 12 dokter umum dan 6 dokter gigi. Jumlah dokter di Kabupaten Buol pada tahun 2016 justru semakin berkurang dan semakin jauh dari kebutuhan standar. Kondisi ini menunjukkan bahwa proses rekrutmen yang dilaksanakan tidak efektif karena belum mampu memenuhi jumlah standar kebutuhan. Tujuan: Untuk mengetahui prosedur rekrutmen dokter di Dinas Kesehatan Kabupaten Buol dan mengidentifikasi faktor yang menghambat rekrutmen dokter di Dinas Kesehatan Kabupaten Buol. MetodePenelitian: Jenis penelitian ini adalah penelitian deskriptif dengan penekatan kualitatif. Informan dalam penelitian ini adalah pihak Dinas Kesehatan dan Dokter yang bekerja di Kabupaten Buol. Kesimpulan: Permasalahan yang terjadi dalam rekrutmen dokter di Kabupaten Buol adalah kurangnya jumlah pelamar. Hal ini dapat disebabkan karena kurangnya minat dan kesediaan dokter untuk bekerja di Kabupaten Buol. Faktor yang mendukung kesediaan dokter untuk bekerja di Kabupaten Buol adalah kompensasi yang sudah sesuai dengan standar gaji untuk wilayah terpencil dan penghargaan serta jenjang karir dimana dokter masih memiliki peluang untuk menjadi PNS dan mendapatkan promosi pendidikan lebih lanjut. Faktor yang menghambat kesediaan dokter untuk bekerja di Kabupaten Buol adalah kondisi kerja yang dinilai sangat berat karena kurangnya jumlah dokter pada Puskesmas rawat inap dan Puskesmas non rawat inap di Kabupaten Buol serta faktor lingkungan yang lebih luas yang dirasa sepi dan terpencil dan menjadi hambatan bagi sebagian dokter.

Kata kunci : rekrutmen, seleksi, dokter

\section{PENDAHULUAN}

Perbandingan antara jumlah tenaga dokter dengan jumlah penduduk yang harus dilayani di Kabupaten Buol menunjukkan bahwa sangat tidak rasional kegiatan pelayanan kesehatan di Buol bisa berjalan sesuai dengan visi dan misi. Mekipun Pemerintah Daerah Kabupaten Buol selalu memakai prinsip efisien dan efektif namun pada kenyataannya masih banyak data yang mengatakan bahwa tidak meratanya jumlah dokter di setiap daerah di Kabupaten Buol sehingga 
Arifandi, dkk.: Faktor yang Mempengaruhi Rekrutmen Dokter

Tabel 1. Sumber Daya Manusia Kesehatan Kabupaten Buol

\begin{tabular}{|c|c|c|c|c|c|c|c|c|c|}
\hline \multirow[b]{2}{*}{ No } & \multirow{2}{*}{$\begin{array}{c}\text { Jenis } \\
\text { Tenaga } \\
\text { Kesehatan }\end{array}$} & \multicolumn{4}{|c|}{2015} & \multicolumn{4}{|c|}{2016} \\
\hline & & Keadaan & $\begin{array}{l}\text { Kebutuhan } \\
\text { Standar }\end{array}$ & Kelebihan & Kekurangan & Keadaan & $\begin{array}{c}\text { Kebutuhan } \\
\text { Standar }\end{array}$ & Kelebihan & Kekurangan \\
\hline 1 & $\begin{array}{l}\text { Dokter } \\
\text { Umum }\end{array}$ & 9 & 15 & 0 & 6 & 3 & 15 & 0 & 12 \\
\hline 2 & $\begin{array}{l}\text { Dokter } \\
\text { Gigi }\end{array}$ & 6 & 11 & 0 & 5 & 5 & 11 & 0 & 6 \\
\hline & JUMLAH & 15 & 26 & 0 & 11 & 8 & 26 & 0 & 18 \\
\hline
\end{tabular}

mengakibatkan rendahnya kualitas pelayanan kesehatan. Hal ini dapat mempengaruhi status kesehatan masyarakat. Berdasarkan data revitalisasi kebijakan dasar pusat kesehatan masyarakat dapat diketahui bahwa banyak Puskesmas di Kabupaten Buol yang kekurangan dokter, bahkan tidak memiliki dokter sama sekali. Keadaan tenaga kesehatan di Kabupaten Buol dapat dilihat pada tabel berikut.

Pada tabel di atas terlihat bahwa jumlah dokter yang dibutuhkan di Kabupaten Buol masih kurang. Pada tahun 2015, jumlah dokter di Kabupaten Buol adalah sebanyak 15 dokter dengan rincian 9 dokter umum dan 6 dokter gigi, sedangkan standarnya adalah 26 dokter dengan rincian 15 dokter umum dan 11 dokter gigi. Oleh karena itu, ada kekurangan sebanyak 11 dokter dengan rincian 6 dokter umum dan 5 dokter gigi. Pada tahun 2016, jumlah dokter di Kabupaten Buol adalah sebanyak 8 dokter dengan rincian 3 dokter umum dan 5 dokkter gigi, sedangkan standarnya adalah 26 dokter dengan rincian 15 dokter umum dan 11 dokter gigi. Oleh karena itu, ada kekurangan sebanyak 18 dokter dengan rincian 12 dokter umum dan 6 dokter gigi. Jumlah dokter di Kabupaten Buol pada tahun 2016 justru semakin berkurang dan semakin jauh dari kebutuhan standar. Kondisi ini menunjukkan bahwa proses rekrutmen yang dilaksanakan belum mampu memenuhi jumlah standar kebutuhan.

Pada saat ini, proses pengadaan dokter yang dilaksanakan Dinas Kesehatan Kabupaten Buol dapat dinilai belum efektif. Hal ini dapat diketahui dari adanya sejumlah masalah yang terkait dengan pengadaan pegawai. Dalam perencanaan kebutuhan tenaga kesehatan Kementerian Kesehatan telah mengeluarkan Keputusan Menteri Kesehatan Nomor 81 Tahun 2004 tentang Penyusunan Perencanaan SDM Kesehatan di Tingkat Propinsi, Kab/Kota serta Rumah Sakit. Dalam keputusan tersebut metoda penghitungan kebutuhan tenaga kesehatan dibagi menjadi: berdasarkan beban kerja, waktu kerja yang tersedia, ratio tenaga kesehatan berbanding penduduk dan beberapa model DSP (Daftar Susunan Pegawai).

Berdasarkan uraian tersebut dapat diketahui bahwa rekrutmen dokter pada Dinas Kesehatan Kabupaten Buol masih mengalami sejumlah masalah. Masalah-masalah yang terjadi berkaitan dengan kurang efektifnya manajemen sumber daya manusia kesehatan terkait dengan pengadaan dokter. Selain itu, ada faktor yang mempengaruhi rekturmen dokter sehingga proses rekrutmen menjadi tidak efektif. Dengan latar belakang diatas, penulis tertarik untuk melakukan penelitian dengan judul "Faktor yang Mempengaruhi Rekrutmen Dokter di Puskesmas Wilayah Kerja Dinas Kesehatan Kabupaten Buol Tahun 2016 ?".

\section{METODE PENELITIAN}

Pendekatan yang digunakan dalam penelitian ini merupakan penelitian studi kasus. Studi kasus lebih cocok bila pertanyaan suatu penelitian berkenaan dengan 'how' atau 'why', bila peneliti hanya memiliki sedikit peluang untuk mengontrol peristiwa-peristiwa yang akan diselidiki, dan bilamana fokus penelitian terletak pada fenomena kontemporer didalam konteks kehidupan nyata. Penelitian studi kasus lebih memusatkan perhatian pada aspek pendesainan dan penyelenggaraannya agar lebih mampu menghadapi permasalahan (Yin, 2009). Penelitian ini difokuskan pada kasus dalam rekrutmen dokter di Kabupaten Buol.

Subjek dalam penelitian ini adalah stakeholder yang ada di Dinas Kesehatan Kabupaten Buol. Secara lebih rinci, informan atau narasumber penelitian ini terdiri dari Kepala Bidang Rekrutmen dan Mutasi Pegawai pada Dinas Kesehatan Kabupaten Buol, Kepala Sub Bidang Rekrutmen serta Kepala Badan dan Dinas, dalam lingkungan Pemerintah Daerah Kabupaten Buol, dan Dokter di Kabupaten Buol sebagai pihak yang merupakan pegawai di Dinas 
Kesehatan Kabupaten Buol. Jumlah total respnden dalam penelitian ini adalah sebanyak 11 orang. Responden dari Dinas Kesehatan Kabupaten Buol terdiri dari 2 orang, yaitu Kepala Bidang SDM dan Sekertaris. Dokter yang menjadi responden penelitian adalah sebanyak 7 orang yang terdiri dari dokter PTT daerah, dokter PTT pusat, dan dokter internsip. Doter yang menjadi responden juga terdiri dari gokter umum dan dokter gigi yang bekerja di Puskesmas di seluruh wilayah Kabupaten Buol. Kepala Puskesmas yang diwawancarai adalah sebanyak 1 orang, yaitu Kepala Puskesmas Modo. Responden lainnya adalah responden dari Badang Kepegawaian Derah Kabupaten Buol dengan jumlah 1 orang.

Variabel dependen dalam penelitian ini adalah efektivitas pelaksanaan rekrutmen. Variabel independen dari penelitian ini adalah kompensasi, kondisi kerja, penghargaan dan jenjang karir, dan lingkungan yang lebih luas. Pengumpulan data dilakukan melalui wawancara dan studi dokumen. Dokumen ini dapat berupa dokumen publik, seperti laporan bulanan maupun laporan tahunan (Cresswel, 2010).

\section{HASIL PENELITIAN}

Gambaran Umum Mekanisme Rekrutmen, Kebutuhan, dan Ketenagaan Dokter di Dinas Kesehatan Kabupaten Buol

Rekrutmen dokter PTT Daerah diawali dengan proses perencanaan melalui analisis kebutuhan. Setelah menghitung kebutuhan jumlah dokter, Dinas Kesehatan Kabupaten Buol melakukan sosialisasi dan penerimaan aplikan. Sosialisasi dilakukan melalui pengumuman secara online menggunakan media sosial. Selain itu, sosialisasi juga dilakukan dengan mengajak dokter yang sudah bekerja di Kabupaten Buol untuk memberikan informasi kepada rekanrekannya. Sosialisasi tersebut bersamaan dengan proses penerimaan surat lamaran dari pelamar. Dinas Kesehatan Kabupaten Buol memberikan sejumlah persyaratan yang harus dipenuhi dalam pengiriman surat lamaran tersebut, seperti halnya fotocopy ijazah, SIP, dan STR.

Setelah proses penerimaan aplikan atau surat lamaran, Dinas Kesehatan Kabupaten Buol melaksanakan proses seleksi. Proses seleksi yang dilakukan hanya berupa seleksi berkas, tidak ada tes tertulis ataupun tes wawancara kerja. Apabila beras sudah lengkap dan sesuai syarat, dokter akan diterima bekerja di Kabupaten Buol. Daftar dokter yang diterima tersebut kemudian diajukan kepada Badan Kepegawaian Daerah Kabupaten Buol untuk memfasilitas pembuatan SK kontrak kerja. Kontrak dilakukan antara Pemerintah Daerah Kabupaten Buol dengan doktor yang diterima. Kontrak kerja dilakukan berdasrkan SK dari Bupati Buol. Setelah kontrak kerja dilaksanakan, dilakukan penempatan dokter di Puskesmas pada seluruh wilayah Kabupaten Buol. Penempatan dokter kemudian dilakukan berdasarkan surat keputusan dari Kepala Dinas Kesehatan Kabupaten Buol.

Analisis kebutuhan jumlah dokter untuk masingmasing Puskesmas di Kabupaten Buol berdasarkan Peraturan Menteri Kesehatan Nomor 75 Tahun 2014 tentang Revitalisasi Puskesmas Melalui Integrasi Program dapat dilihat pada tabel berikut.

Tabel 2. Jumlah Kebutuhan Dokter di Kabupaten Buol

\begin{tabular}{|c|c|c|c|c|c|c|}
\hline \multirow{2}{*}{ No. } & \multirow{2}{*}{ Puskesmas } & \multirow{2}{*}{ Jenis Pelayanan } & \multicolumn{2}{|c|}{ Kebutuhan Dokter } & \multicolumn{2}{|c|}{ Ketenagaan Dokter } \\
\hline & & & Dokter Umum & Dokter Gigi & Dokter Umum & Dokter Gigi \\
\hline 1 & Lakea & Perawatan & 2 & 1 & 0 & 0 \\
\hline 2 & Biau & Non Perawatan & 1 & 1 & 1 & 1 \\
\hline 3 & Karamat & Non Perawatan & 1 & 1 & 0 & 1 \\
\hline 4 & Momunu & Non Perawatan & 1 & 1 & 1 & 1 \\
\hline 5 & Boilan & Non Perawatan & 1 & 1 & 0 & 1 \\
\hline 6 & Bokat & Non Perawatan & 1 & 1 & 1 & 2 \\
\hline 7 & Modo & Perawatan & 2 & 1 & 0 & 1 \\
\hline 8 & Bunobogu & Perawatan & 2 & 1 & 1 & 1 \\
\hline 9 & Gadung & Non Perawatan & 1 & 1 & 0 & 0 \\
\hline 10 & Paleleh & Perawatan & 2 & 1 & 0 & 0 \\
\hline 11 & Timbulon & Non Perawatan & 1 & 1 & 0 & 0 \\
\hline \multicolumn{3}{|c|}{ Jumlah } & 15 & 11 & 4 & 8 \\
\hline
\end{tabular}


Berdasarkan Tabel 2 dapat dilihat jumlah kebutuhan dokter pada masing-masing Puskesmas. Sampai dengan saat ini, jumlah dokter yang ada di Kabupaten Buol, khususnya pada Puskesmas di Kabupaten Buol belum sesuai dengan jumlah kebutuhan sebagaimana yang terdapat pada tabel di atas. Apabila disesuaikan dengan kebutuhan jumlah tenaga dokter pada terlihat bahwa masih terdapat banyak kekurangan jumlah dokter untuk keseluruhan Puskesmas di Kabupaten Buol. Jumlah kebutuhan dokter untuk seluruh Puskesmas di Kabupaten Buol adalah sebanyak 26 dokter yang terdiri dari 15 dokter umum dan 11 dokter gigi, sedangkan jumlah yang ada secara riil adalah sebanyak 12 dokter yang terdiri dari 4 dokter umum dan 8 dokter gigi. Oleh karena itu, kekurangan jumlah dokter adalah sebanyak 14 dokter yang terdiri dari 11 dokter umum dan 3 dokter gigi.

\section{Kompensasi dan Remunerasi bagi Dokter di Kabupaten Buol Standar Gaji}

Standar gaji dokter yang ditetapkan oleh pemerintah pusat adalah standar untuk semua dokter di seluruh wilayah Indonesia. Menurut Peraturan Menteri Kesehatan Nomor 7 Tahun 2013 tentang Pedoman Pengangkatan dan Penempatan Dokter dan Bidan Sebagai Pegawai Tidak Tetap, standar gaji bagi dokter dan dokter gigi yang ditempatkan sebagai dokter PTT di Indonesia seharusnya diberikan gaji dan insentif sebesar Rp 5.267.900,- per bulan untuk daerah terpencil dan sebesar Rp 7.659.950,- per bulan untuk daerah sangat terpencil. Gaji tersebut diharapkan dapat digunakan oleh dokter untuk memenuhi kebutuhan hidup di daerah. Adapun biaya utama yang dikeluarkan oleh dokter adalah untuk biaya perumahan, makanan, sekolah, dan kegiatan sosial lainnya. Terkait dengan kompensasi, berikut pendapat dari informan penelitian.

"Kita, kebijakan yang diberikan itu, seperti rumah, Puskesmas sudah siapkan, ada rumah dokter. Begitu juga kendaraan, ada kendaraan Puskesmas, kemudian gajinya. Gaji kita berikan 7,5 juta perbulan. Selain biaya-biaya seperti jasa Puskesmas (Responden 1)".

Terkait dengan kompensasi, berikut pendapat dari informan penelitian.

"Ya biasanya kalau dokter-dokter yang kita kontrak, selain gaji ada hak-hak mereka seperti jasa pemeriksaan, tindakan, itu tetap dibayarkan. Sistem penggajian karena kita pakai kontrak maka kita pakai APBD, ada standar dari pemerintah daerah. Sebenarnya patokan gaji kita dari PTT pusat. Gaji bervariasi, tergantung daerah. Daerah dikategorikan menjadi 3, biasa, terpencil, dan sangat terpencil. Gaji tergantung daerah, sangat terpencil dan terpencil lebih besar. Kalau sekarang 7,5 juta di Kabupaten Buol, karena termasuk daerah terpencil (Responden 2)".

Berdasarkan hasil wawancara di atas dapat dipahami bahwa sistem kompensasi dari Dinas Kesehatan Kabupaten Buol dilakukan sudah cukup baik dan sesuai dengan standar gaji dokter dari Kementerian Kesehatan pusat. Dokter menerima gaji PTT sebesar Rp. 7.500.000, sesuai dengan standar gaji dokter pada daerah sangat terpencil. Ada dokter yang sudah menerima gaji sesuai dengan kontrak kerja. Namun demikian, permaslahaan yang terjadi lebih berkaitan dengan lamanya kontrak kerja diterima oleh dokter sehingga penerimaan gaji juga mengalami kemunduran karena belm siapnya kontrak kerja sementara dokter sudah mulai bekerja di Puskesmas wilayah Kabupaten Buol.

\section{Pendapatan Lainnya}

Selain gaji yang diterima, dokter juga memiliki pendapatan lainnya, seperti insentif daerah, tunjangan kinerja, penghasilan jasa dari Puskes, JKN, dan TKD, serta pendapatan dari praktik pribadi. Secara teoritis, lembaga pelayanan kesehatan dapat menyisihkan sebagian keuntungan untuk bonus staf. Keputusan tersebut seringkali disebut sebagai pembagian keuntungan, dimana tunjangan yang diberikan tidak boleh lebih dari tiga kali jumlah gaji. Bonus tersebut dimaksudkan untuk memberi penghargaan atas produktivitas, namun biasanya dibagikan dengan menggunakan formula standar yang tidak mencerminkan aktivitas aktual. Bonus tersebut tidak diungkapkan secara terbuka. Terkait dengan pendapatan lainnya, berikut pendapat responden penelitian.

\footnotetext{
"Ya yang mereka diterima gaji dengan jasa." (Responden 1)

"Belum ada, tapi kita memang ada rencana begitu. Jadi untuk daerah yang sangat terpencil, untuk yang aksesnya agak sulit itu kita akan berikan reward kepada mereka. kalau pelayanan mereka bagus maka kita akan berikan reward kepada mereka." (Responden 2)
}

"Kalau tunjangan sih tidak ada tunjangan lain. Kita orang hanya dapat gaji pokok PTT dan jasa. Jasa itu yang dari Puskesmas." (Respoden 3)

"Kalau ini saya dengar ada, tunjangan, insentif dari Puskesmas, itu yang berupa JKN dan Jamkesda, di 
luar dari upah yang diberikan dari dinas kesehatan. Tapi besarannya saya belum tahu." (Responden 9)

Berdasarkan informasi dari hasil wawancara di atas dapat diketahui bahwa dokter PTT daerah maupun PTT pusat juga menerima pendapatann jasa dari Puskesmas, JKN, dan TKD walaupun besarannya tidak dapat ditentukan. Namun demikian, untuk tunjangan kinerja masih menjadi wacana oleh Dinas Kesehatan Kabupaten Buol. Dinas Kesehatan Kabupaten Buol Isudah memiliki rencana untuk memberikan tunjangan kinerja atau reward kepada dokter yang bekerja dengan kinerja yag lain. namun demikian, hal ini masih sebatas wacana karnea masih mengalami beberapa kendala. Untuk masa yang akan datang, Dinas Kesehatan Kabupaten Buol merencanakan hal ini dapat terwujud pada tahun 2018.

\section{Peluang untuk Membuka Praktik Pribadi}

Dinas Kesehatan Kabupaten Buol memberikan kesempatan bagi dokter untuk membuka praktik pribadi. Hal ini dapat diketahui dari informasi responden berikut ini.

\begin{abstract}
"Kalau praktik itu bebas mereka, bisa saja mereka, sepanjang tidak mengganggu kedinasan tidak masalah." (Responden 2)
\end{abstract}

"Oh iya, memang begini, masalah kita orang membuka praktik pribadi toh? Setiap dokter yang lulus dari pendidikan dokter, dokter mendapatkan surat tanda registrasi dokter. Surat tanda registrasi dokter itu diberikan 3 yang dilegalisir. Artinya, setiap dokter itu, hanya bisa memiliki 3 tempat prakik. Kalau di Buol sih itu, Alhamdulillah dia orang kasih kita punya hak itu sesuai." (Responden 3 )

"Pernah saya tanya gitu, terus jawabanya harus ada apotik. Jadi harus ada kerjasama dengan apotik, harus ada SIP. Tapi ada peluang untuk membuka praktik, yang ada persyaratannya, kerjasama dengan apotik." (Responden 4)

Berdasarkan informasi dari responden penelitian dapat diketahui bahwa Dinas Kesehatan Kabupaten Buol membuka peluang bagi dokter untuk membuka atau melaksanakan praktik pribadi. Namun demikian, peluang ini diberikan dengan syarat utama tidak mengganggu pekerjaan dokter secara kedinasan. Selain itu, ada ketentuan lain yang harus dipatuhi dokter dalam membuka praktik pribadi. Ketentuan lain tersebut diantaraya harus ada kerjasama dengan apotik dan harus ada SIP. Sudah ada beberapa dokter Puskesmas yang juga membka praktik pribadi di daerah Kabupaten Buol, terutama pada dokter yang tinggal di kota.

\section{Kondisi Kerja Dokter di Kabupaten Buol Keadaan Peralatan Kerja}

Selama melakukan pekerjaan, setiap pegawai termasuk dokter akan berinteraksi dengan berbagai kondisi yang terdapat dalam lingkungan kerja. Kondisi tersebut termasuk keadaan peralatan kerja

“Fasilitas di Puskesmas saya rasa cukup. Dari peralatan saya rasa juga cukup. Kondisi lingungan kerja sudah mendukung untuk pelaksanaan kerja dengan baik. Fasilitas Puskesmas kondisinya baik. Mestinya semua peralatan juga dalam kondisi bagus. Beban dokter untuk di Kabupaten Buol yang karena seharusnya ada 2 dokter tapi hanya ada 1 ya berat. kalau dia perawatan lalu digabung dengan poli ya pasti berat (Responden 1)".

Responden lainnya memberikan informasi sebagaimana berikut.

\begin{abstract}
"Fasilitas sudah memadai, tidak ada kekurangan. Peralatan mencukupi. Kondisi lingkungan kerja, dominan lebih banyak mereka senang dengan kondisi kerja. Fasilitas dan peralatan penunjang kondisinya memadai. Misalnya dokter gigi, peralatan yang ada sudah termasuk canggih. Ya permasalahannya beban kerja, karena masih sangat kurang dokternya. Di Puskesmas rawat inap seharusnya ada 2 dokter, tapi karena adanya hanya 1 dokter ya jadi berat (Responden 2)".
\end{abstract}

Informan dokter memberikan pendapat yang berbeda terkait kondisi kerja sebagaimana kutipan berikut.

"Fasilitas masih kurang. Kalau dari alat sudah mencukupi, tapi dari bahan, termauk obat-obatan itu mmasih kurang. Di Puskemas yang jauh dari kota dan dari BPJS yang menekan jumlah rujukan maka obat-obatan termasuk kurang. Lingkungan kerja sih baik, tapi alangkah baiknya kalau perawatan tambah 1 dokter. (Responden 3)".

"Fasilitas mungkin kalau hanya untuk standarstandar saja sudah bisa. Tapi kalau untuk pemeriksaan lab dan yang lebih lengkap kan tidak ada disini. Peralatan medis masih kurang. Fasilitas ruangannya juga kurang. Kalau lingkungan kerja kondisi secara keseluruhan sudah mendukung sih, munggkin tenaganya yang kurang, lalu penempatannya kurang pas (Responden 4)".

Berdasarkan hasil penelitian di atas diperoleh informasi bahwa fasilitas dasar sudah mencukupi dan berada dalam kondisi cukup memadai. Namun demikian, untuk fasilitas kesehatan yang lebih lengkap belum mencukupi pada Puskesmas di Kabupaten Buol. Sebagaimana diketahui bersama bahwa fasilitas yang baik dan peralatan kesehatan berteknologi tinggi lebih menarik bagi pasien. Oleh karena itu, fasilitas peralatan merupakan salah satu 
faktor penentu dari pendapatan yang diperoleh dari pasien.

\section{Kondisi Lingkungan Kerja}

Kondisi lingkungan kerja juga mempengaruhi kesediaan dokter untuk menerima pekerjaan. Kondisi kerja di daerah terpencil kemungkinan akan kurang memuaskan bagi dokter. Kondisi kerja mencakup banyak dimensi, selain peralatan yang kurang canggih, para dokter sering kurang memiliki kemampuan untuk berlatih dan memperluas keterampilan mereka, stimulasi intelektual kurang, rekan-rekan yang kurang berpengalaman, pasien miskin dan pemanfaatan yang lebih rendah dari fasilitas umum. Kondisi kerja di pedesaan yang menjadi aspek yang mempengaruhi efektivitas rekrutmen dokter antara lain ketersediaan peralatan, kondisi lingkungan kerja, dan beban kerja.

Selain peralatan, dalam melaksanaan pekerjaan dokter juga membutuhkan kondisi lingkungan kerja yang kondusif. Kondisi kerja yang kurang memuaskan dapat mempengaruhi kinerja dokter. Konisi lingkungan kerja pada dasarnya mencakup banyak dimensi, selain peralatan yang kurang canggih, para dokter seringkali kurang memiliki kemampuan untuk berlatih dan memperluas keterampilan, stimulasi intelektual, rekan kerja yang kurang berpengalaman, pasien dengan tingkat pendidikan yang rendah, dan kualitas fasilitas kerja yang lebih rendah secara umum. Kondisi lingkungan kerja diungkapkan oleh responden dalam kutipan wawancara berikut.

\footnotetext{
"Ya, sudah lumayan bagus sih sekarang. Disini itu fasilitasnya memang bagus. Dulu disini kan banyak pasien sesak. Dulu disini tidak ada alat nebu. Alat nebu itu alat uap, sekarang ada tapi masalahnya obatnya tidak ada. Jadi masalahnya walaupun fasilitasnya ada tapi kalau penunjang tidak ada sama saja susah." (Responden 3)
}

"Sudah mendukung sih, cuma mungkin tenagatenaga lainnya yang harus ditingkatkan. Mungkin ini disini, perawat ditempatkan di apotik misalnya, jadi penepatannya itu kurang tepat, kurang mendukung pekerjaan dokter." (Responden 4)

Berdasarkan hasil wawancara di atas dapat dipahami bahwa pada dasarnya kondisi lingkungan kerja cukup baik di beberapa Puskesmas. Namun demikian, masih sangat dibutuhkan perbaikan serperti kebutuhan ruangan dan juga pengaturan tugas tenaga kesehatan lainnya. Responden lain juga memberikan pendapat mengenai pembagian tugas yang kurang baik sebagaimana hasil wawancara berikut.

\begin{abstract}
"Pembagian tugas yang kurang bagus. Dibilang mendukung sekali sih tidak, kurang juga tidak. Jadi tergantung kita saja. Misalnya disini kan tidak ada asisten, disana ada asisten, sehingga terpaksa kalau panggil pasien kan terpaksa saya sendiri yang panggil. harusnya kan ada asisten, panggil pasien, menemani, kan begitu. Ini tidak ada, jadi semua dikerjakan sendiri. Karena kekurangan tenaga." (Responden 5)
\end{abstract}

Hasil wawancara di atas menunjukkan bahwa dokter-dokter menilai bahwa pembagian tugas kurang baik. Ada Puskesmas yang menematkan perawat di bagian apotik sehingga kinerja pada bagian apotik menjadi kurang baik. Hal ini dapat terjadi karena keterbatasan tenaga kesehatan lainnya selain dokter sehingga tenaga kesehatan harus melakukan pekerjaan yang seharusnya tidak menjadi bidangnya. Salah satu keprihatinan yang diungkapkan oleh dokter yang diwawancarai adalah kurangnya tenaga kesehatan sehingga dokter haru melakukan berbagai pekerjaan.

\section{Beban Kerja}

Terkait dengan beban kerja dokter di kabupaten Buol, berikut pendapat dari responden penelitian.

\begin{abstract}
"Beban dokter untuk di Kabupaten Buol yang karena seharusnya ada 2 dokter tapi hanya ada 1 ya berat. kalau dia perawatan lalu digabung dengan poli ya pasti berat." (Responden 1)

"Ya, itu tadi permasalahannya beban kerja, karena masih sangat kurang dokternya. Di Puskesmas rawat inap itu kan seharusnya minimal ada 2 dokter, tapi karena adanya hanya 1 dokter ya jadi berat." (Responden 2)
\end{abstract}

Hasil wawancara di atas menunjukkan bahwa dokter tidak terlalu merasa terbebani dengan beban kerja di Puskesmas. Beban kerja yang tinggi tidak tejadi setiap saat, hanya pada saat pasien banyak saja. Dokter yang merasa beban kerja tidak begitu tinggi adalah dokter yang berada di Puskesmas non rawat inap. Perlu disadari bahwa profesi dokter sudah terlatif untuk menghadapi beban kerja yang tinggi. Setiap jenis pekerjaan memiliki tantangan sendiri, yang bisa menimbulkan perasaan stres dan depresi bagi yang melakukannya.

\section{Penghargaan dan Jenjang Karir Dukungan dan Supervisi}

Dukungan dan pengawasn kepada dokter dapat diketahui dari kutipan berikut.

"Kita hanya menginformasikan bahwa setiap Puskesmas, harus memberikan, kendaraan 
dengan tempat tinggalnya harus disiapkan... Pengawasannya ini yang melaksanakan kepala dinas, sekertaris, Kasubag Kepegawaian dengan Bdang SDM." (Responden 1)

"Ya itulah, kami selain memberikan fasilitas sarana prasarana, kita jasa-jasa yang lain kita tidak hilangkan, itu tetap ada. Misalnya dari JOK, dari JKN tu tetap ada. Kalau jenjang karir tidak ada karena mereka kan kontrak bukan PNS. Kalau pengembangan, untuk pendidikan belum ada karena belum PNS, pelatihan ada.... Ya ada untuk pengawasan dan evaluasi kinerja dokter ada, setiap 3 bulan kita laksanakan kinerja." (Responden 2)

Pihak Dinas Kesehatan berpandangan bahwa fasilitas sarana dan prasarana yang diberikan merupakan bentuk dukungan terhadap dokter di Kabupaten Buol. Adapun fasilitas yang diberikan adalah tempat tinggal dan kendaraan. Menurut informasi ini, pengawasan sudah dilakukan oleh Dinas Kesehatan dengan pengukuran kinerja yang dilakukan sekali 3 bulan. Namun demikian, pendapat ini berbeda dengan pendapat dokter. Dokter merasa Dinas Kesehatan belum memberikan dukungan dan pengawasan.

\section{Hubungan Sosial}

Di Kabupaten Buol, dokter melaporkan hubungan yang memuaskan dengan rekan kerja, karena rekan kerja dapat saling membantu, dan tidak ada diskriminasi di antara mereka. Namun, hubungan dengan masyarakat tidak selalu mulus. Hubungan yang tegang antara dokter dan masyarakat lebih mungkin terjadi dalam pemberian jenis pengobatan. Berikut informasi dari rsponden penelitian terkait dengan hubungan sosial.

\begin{abstract}
"Ya sih, kalau ini kan beragam, namanya masyarakat. Jadi ada yang bisa menerima penjelasan, ada yang tidak, jadi ada pasien yang ingin ditindaki menurut keinginan mereka. Jadi misalnya tindakan itu tidak perlu, tapi meminta. Ada juga kadang mengatur tindakan yang harus dilakukan." (Responden 5)
\end{abstract}

\footnotetext{
"Hubungan dokter dengan lingkungan sosial baik, perawat-perawatnya wellcome gitulah, menyambut dengan hangat, kerjasamanya juga bagus." (Responden 5)
}

Hasil wawancara di atas menunjukkan bahwa tenaga kesheatan lainnya bersikap baik kepada dokter sehingga hubungan sosial dalam pekerjaan berlangsung dengan baik. Hubungan sosial yang baik mendukung pekerjaan dokter. Namun demikian, hubungan sosial yang kadang menyulitkan dokter terkait dengan hubungan dkter dengan masyarakat yang menerima pelaanan.
Terkadang ada pasien yang tidak bisa menerima penjelasan mengenai tindakan yang harus dilaksanakan. Pasien cenderung menginginkan dokter beritindak sesuai dengan keinginan mereka. Hal inilah yang menjadi beban bagi dokter dalam melaksanakan pekerjaannya.

\section{Pengembangan Karir}

Berkaitan dengan peghargaan dan jenjang karir, berikut pendapat dari responden penelitian.

\begin{abstract}
"Penghargaan ada bagi yang memiliki kinerja baik. Kalau promosi dokter, kita tidak ada. Untuk rekomendasi kita kepada Pemerintah Provinsi. Kalau untuk pengembangan karis, ada pelatihan. Dokter diberikan kesematan untuk pelatihan (Responden 1)".
\end{abstract}

Responden lainnya memberikan informasi sebagaimana berikut.

\begin{abstract}
"Ya itulah, kami selain memberikan fasilitas sarana prasarana, kita jasa-jasa yang lain kita tidak hilangkan. Untuk pengawasan dan evaluasi kinerja dokter ada, setiap 3 bulan kita laksanakan kinerja. Kalau jenjang karir tidak ada karena mereka kan kontrak bukan PNS. Kalau pengembangan, untuk pendidikan belum ada karena belum PNS, pelatihan ada (Responden 2)".
\end{abstract}

Berdasarkan hasil penelitian di atas diperoleh informasi bahwa Dinas Kesehatan Kabupaten Buol sudah cukup mendukung dalam pengembangan karir dokter. Dinas Kesehatan Kabupaten Buol sudah memberikan kesempatan yang cukup besar bagi dokter untuk mengikuti pelatihan-pelatihan. Namun demikian, karena dokter pada Puskesmas masih berstaus sebagai tenaga kontrak daerah dan belum berstatus PNS maka belum ada peluang untuk mengikuti pendidikan lanjut dan juga belum ada kesempatan ntuk mengembangkan karir lebih jauh. akan tetapi, sebagian dokter menilai bahwa dokter di Kabupaten Buol walaupun masih berstatus sebagai tenaga kontrak namun memiliki peluang yang cukup besar untuk menjadi PNS dan menempuh pendidikan lanjut sebagai dokter spesialis yang dibutuhkan di Kabupaten Buol.

\section{Akses Mengikuti Pelatihan}

Berikut pendapat responden mengenai akses bagi dokter untuk mengikuti pelatihan.

\footnotetext{
"Kalau ini kita lakukan, kita tidak membedabedakan. Jadi kalau ada pelatihan-pelatihan di luar yang diadakan provinsi atau pusat, itu kita sepanjang diminta dokter, itu kita berikan mereka." (Responden 2)
} 


\begin{abstract}
"Aksesnya ada sih lewat darat, pelatihannya pernah saya ikuti di Palu di Toli-toli." (Responden 5)

"Ada sih kalau itu, pelatihan." (Responden 5)

"Training untuk saat ini belum ada training, saya juga baru masuk kesini. Tapi secara umum masih bisalah, masih ada jalur, tapi untuk training itu biasanya lewat informasi dari teman-teman, Ialu nanti berkoordinasi dengan kepala Puskesmas." (Responden 9)
\end{abstract}

Berdasarkan kutipan wawancara di atas dapat diketahui bahwa Dinas Kesehatan Kabupaten Buol memberikan akses pelatihan bagi dokter. Pelatihan juga dibuka bagi dokter PTT daerah ataupunn PTT pusat. Namun demikian, tidak semua dokter merasa memperoleh kesempatan mengikuti pelatihan. Pemerintah daerah dapat menawarkan untuk memberikan pelatihan tanpa membedakan dokter umum dan dokter gigi. Wawancara mendalam menunjukkan bahwa tidak banyak kesempatan pelatihan bagi dokter yang bekerja di sebagai dokter gigi.

\section{Lingkungan yang Lebih Luas Bagi Tenaga Dokter di Kabupaten Buol \\ Perumahan}

Ada beberapa dokter yang tinggal di perumahan yang diberikan sebagai fasilitas dari Dinas Kesehatan. Namun demikian, ada juga dokter yang tidak tinggal di fasilitas rumah yang diberikan karena merasa bahwa rumah tersebut tidak layak. Berikut informasi mengenai perumahan di Kabupaten Buol.

\footnotetext{
"Ya, hampir semua Puskesmas ada fasilitas rumah dokter. (Responden 2)

"Tempat tinggal yang diberikan kepada saya layak, cukup. kalau fasilitas rumah setiap Puskemas beda, karena tergantung setiap Puskesmas. Kalau di Puskesmas saya sih sangat memuaskan." (Responden 3)
}

“Ada, disediakan, rumahnya memadai.” (Responden 4)

"Ya, cukuplah, bantuan rumah cukup walaupun saya tidak tinggal disitu. Saya tinggal di kota." (Responden 5)

Hasil wawancara di atas menunjukkan bahwa dokter merasa cukup puas dengan fasilitas perumahan yang disediakan Dinas Kesehatan kabupaten Buol. Adapun jarak rumah dinas tersebut dari Puskesmas sanat dekat sehingga dokter tidak memerlukan fasilitas transportasi yang sulit. Hasil wawancara di atas menunjukkan bahwa responden merasa rumah yang diberikan kurang memadai. Ada dokter yang tidak menempati rumah yang diberikan Dinas Kesehatan sebagai fasilitas dengan alasan rumah yang diberikan dalam kondisi rusak dan tidak memadai. Ada pula dokter yang merenovasi sendiri rumah yang diberikan sebagai fasilitas bagi dokter. Secara keseluruhan dapat dilihat bahwa Dinas Kesehatan Kabupaten Buol sudah mengupayakan untuk memberikan fasilitas perumahan, walaupun ada yang masih berada dalam kondisi kurang baik.

\section{Pendidikan Untuk Keluarga}

Berkatan dengan ketersediaan pendidikan bagi keluarga dokter berikuti pendapat dari responden penelitian.

"Oh, untuk sekolah anak? Semua ada sekolah." (Responden1)

"Kalau untuk sekolah ada di depan rumah. Cuma kalau untuk tambahan, misalnya saya kasih kursus itu tidak ada disini. Saya mau kasih kursus Bahasa Inggris ndak ada. Itulah yang kurang." (Responden 4)

“lya, masih kurang." (Responden 5)

Semua orang tua berharap anaknya memperoleh pendidikan yang layak dan memadai. Begitu pula halnya dengan dokter yang bekerja di Kabupaten Buol. Pendidikan yang tersedia bagi anak di Kabupaten Buol adalah masih menjadi salah satu penghambat bagi kesediaan dokter. Dokter merasa bahwa fasilitas pendidikan bagi anaknya masih kurang. Apabila dilihat dari ketersediaan fasilitas pendidikan memang diperoleh informasi bahwa sudah ada sekolah-sekolah umum yang ada di dekat rumah dokter. Namun demikian, belum ada lembaga pendidikan lainnya yang dapat meningkatkan kemampuan dan kompetensi anak seperti halnya kursus. Hal ini menyebabkan dokter menilai bahwa fasilitas penndidikan di Kabuoaten Buol masih kurang.

\section{Kondisi Hidup di Daerah Secara Umum}

Berikut pendapat dari responden penelitian mengeai lingkungan yang lebih luas.

“Akses komunikasi mungkin masih sulit, kadang jaringan komunikasi tidak ada signalnya. Tapi lingkungan sosialnya saya rasa baik." (Responden 1)

Responden lainnya memberikan informasi sebagaimana berikut.

\footnotetext{
"Lingkungan Kabupaten Buol selama ini masih sangat kondusif. Lingkungan sosial baik." (Responden 2)
} 
Responden dokter memberikan pendapat terkait kondisi kerja sebagaimana kutipan berikut.

"Umumnya lingkungan, disini sih masyarakat bagus, bersahabat, cuma sepi, terlalu sepi." (Responden 3)

"Keseluruhan? Sunyi (suara ketawa). Lingkungan sosial baik. (Responden 4)".

Berdasarkan hasil penelitian di atas diperoleh informasi bahwa lingkungan yang lebih luas di Kabupaten Buol sudah cukup baik. Lingkungan sosial di Kabupaten Buol sangat baik, dengan masyarakat yag ramah dan akrab. Namun demikian, akses komunikasi masih terbilang sulit. Hal ini disebabkan jaringan komunikasi seluler yang masih terbatas sehinga menyebabkan signal kemunikasi karang terputus.

Berdasarkan hasil wawancara di atas dapat dipehami bahwa pelaksanaan rekrutmen dinilai sudah efektif. Rekrutmen dilakukan melalui proses analisis kebutuhan, proses sosialisasi dan pengelolaan aplikasi, penyaringan kandidat, penerimaan, penempatan, kemudian juga pelaporan dan evaluasi. Namun demikian, kurangnya kecukupan jumlah dokter disebabkkan karena kurangnya minat dokter untuk melamar dan bekerja di Kabupaten Buol. Ada beberapa faktor yang dapat mempengaruhi minat dan kesediaan dokter tersebut, antara lain faktor kompensasi yang diterima, sarana prasarana dan infrastruktur daerah, serta kondisi daerah. Berikut uraian dari beberapa faktor yang dapat mempengaruhi kesediaan dokter untuk bekerja di Kabupaten Buol.

\section{PEMBAHASAN}

Permasalahan Dalam Pelaksanaan Rekrutmen Dokter di Dinas Kesehatan Kabupaten Buol

Jumlah dokter di Puskesmas di Kabupaten

Buol belum mencukupi dan belum sesuai denan jumlah kebutuhan. Masih banyak Puskesmas di Kabupaten Buol yang belum memiliki jumlah dokter sesuai dengan kebutuhan, bahkan ada Puskesmas rawat inap yang tidak memiliki dokter sama sekali. Berikut pembahasan hasil penelitian terkait permasalahan dalam pelaksanaan rekrutmen dokter di Kabupaten Buol dan faktor-faktor yang mempengaruhi kesediaan dokter untuk bekerja di Kabupaten Buol.

\section{Kompensasi bagi Dokter di Kabupaten Buol}

Kompensasi dan sistem penggajian sudah diimplementasikan dengan baik oleh Pemerintah Daerah Kabupaten Buol. Standar gaji bagi dokter di Kabupaten Buol ditetapkan sesuai dengan
Peraturan Menteri Kesehatan Nomor 7 Tahun 2013 tentang Pedoman Pengangkatan dan Penempatan Dokter dan Bidan Sebagai Pegawai Tidak Tetap, standar gaji bagi dokter dan dokter gigi yang ditempatkan sebagai dokter PTT di Indonesia seharusnya diberikan gaji dan insentif sebesar Rp 5.267.900,- per bulan untuk daerah terpencil dan sebesar Rp 7.659.950,- per bulan untuk daerah sangat terpencil. Di Kabupaten Buol, dokter PTT daerah dan PTT pusat menerima gaji sebanyak Rp. 7.500.000,-. Jumlah ini sudah sesuai dengan standar gaji dokter untuk daerah sangat terpencil setelah dipotong dengan pajak penghasilan dan iuran kesehatan. Seluruh dokter menerima gaji sebanyak RP. 7.500.000,-. Jumlah terebut kemudian ditambah dengan penghasilan jasa kesehatan Puskesmas dari JKN dan JKD. Pada doter PTT Pusat, kompensasi yang diterima juga ditambah dengan insentif dari daerah yang berjumlah Rp. 2.356.380,- sampai dengan Rp. 2.847.260,-. kompensasi yang diterima dokter juga bisa bertambah apabila dokter membuka praktik pribadi. Dinas Kesehatan Kabupaten Buol memberikan ijin kepada dokter untuk membuka praktik pribadi.

\section{Kondisi Kerja bagi Dokter di Kabupaten Buol}

Pada dasarnya, penentuan kebutuhan dokter yang dilaksanakan oleh Dinas Kesehatan Kabupaten Buol sudah sesuai dengan Peraturan Menteri Kesehatan Nomor 75 Tahun 2014 tentang Revitalisasi Puskesmas Melalui Integrasi Program. Menurut Peraturan Menteri Kesehatan Nomor 75 Tahun 2014 tentang Revitalisasi Puskesmas Melalui Integrasi Program, pada Puskesmas di kawan terpencil dan sangat terpencil, jumlah dokter pada Puskesmas Rawat Inap adalah sebanyak 2 dokter layanan primer dan 1 dokter gigi, sedangkan pada Puskesmas Non Rawat Inap adalah sebanyak 1 dokter layanan primer dan 1 dokter gigi.

Perhitungan jumlah kebutuhan dokter di Kabupaten Buol yang dilakukan oleh Dinas Kesehatan Kabupaten Buol sudah sesuai dengan standar tenaga dokter minimal Puskesmas berdasarkan Peraturan Menteri Kesehatan Nomor 75 Tahun 2014 tentang Revitalisasi Puskesmas Melalui Integrasi Program tesebut. Puskesmas di Kabupaten Buol terdiri dari 4 Puskesmas rawat inap dan 7 Puskesmas non rawat inap. Jumlah kebutuhan dokter untuk seluruh Puskesmas tersebut adalah sebanyak 26 orang dokter yang terdiri dari 15 dokter umum dan 11 dokter gigi. Namun demikian, sampai dengan saat ini jumlah 
kebutuhan dokter di Kabupaten Buol masih belum mencukupi. Jumlah seluruh dokter yang bekerja di Puskesmas wilayah Kabupaten Buol hanya sebanya 12 orang yang terdiri dari 4 dokter umum dan 8 dokter gigi. terlihat Akibatnya, sangat banyak kekosongan dokter pada Puskesmas di Kabupaten Buol, bahkan ada Puskesmas Rawat Inap yang tidak memiliki tenaga dokter sama sekali. Hal inilah yang menyebabkan beban kerja bagi dokter yang bekerja di Puskesmas wilayah Kabupaten Buol menjadi sangat tinggi.

\section{Penghargaan dan Jenjang Karir bagi Dokter di Kabupaten Buol}

Sejauh ini, peraturan pemerintah mengenai jenjang karir dokter diatur oleh Kementrian Pusat. Peraturan tersebut seringkali dinilai cukup memberatkan bagi dokter. Sistem birokrasi untuk menjadi dokter profesional di Indonesia terkesan bercabang. Sebelumnya, pemerintah sudah menjalankan sistem dokter pegawai tidak tetap (PTT), namun kemudian ditambah dengan program internsip dokter. Program ini mulai muncul sejak diberlakukannya proyek Dikti yakni Worksforce and Service (HWS) pada tahun 2003. Program ini dilaksanakan dengan tujuan untuk mengaplikasikan Kurikulum Berbasis Kompetensi (KBK) di instansi pendidikan dokter seluruh Indonesia. Hal ini mengacu pada SK Mendiknas RI No.045/SK/2002 serta SK Dirjen Dikti Depdiknas RI No. 1386/D/T/2004. Setiap lulusan dokter baru produk kurikulum KBK harus mengikuti program dokter internsip selama 1 tahun sebelum mendapatkan STR (Surat Tanda Registrasi) tetap yang nantinya bisa dipakai untuk mengurus Surat ljin Praktek (SIP) mandiri.

Jenjang karir dan penghargaan bagi dokter juga dapat diwujudkan dalam program pendidikan dan pelatihan. Berdasarkan Undangundang Nomor 36 tahun 2014 tentang Tenaga Kesehatan, pemerintah dan pemerintah daerah berwenang untuk melakukan pengadaan tenaga kesehatan dan melakukan pendayagunaan melalui pemerataan, pemanfaatan dan pengembangan, membina, mengawasi, dan meningkatkan mutu tenaga kesehatan melalui pembinaan dan pengawasan pelaksanaan praktik tenaga kesehatan. Wujud dari pengembangan, pembinaan, dan peningkatan mutu tenaga kesehatan tersebut dapat dilakukan melalui pendidikan dan pelatihan. Di Kabupaten Buol, dokter yang berstatus PTT pusat maupun PTT daerah memiliki kesempatan untuk mengikuti pelatihan dengan fasilitas dari Dinas Kesehatan Kabupaten Buol. Namun demikian, Dinas Kesehatan Kabupaten Buol belum meberikan kesempatan secara merata. Hal ini disebabkan masih ada dokter yang merasa tidak memperoleh kesempatan untuk mengikuti pelatihan, khususnya dokter gigi. Kurangnya pemerataan kesempatan memperoleh pelatihan ini dapat terjadi karena jumlah dokter gigi yang masih cukup banyak dibandingkan dokter umum yang dinilai kurang sehingga mutu dokter yang ada harus terus ditingkatkan.

\section{Lingkungan yang Lebih Luas bagi Dokter di Kabupaten Buol \\ Pemerintah Indonesia sepeuhnya} menyadari bahwa banyak daerah di Indonesia yang masih sulit diakses melalui berbagai model transportasi. Oleh karena itu, dalam berbagai peraturan bagi tenaga kesehatan yang ditetapkan oleh Kementrian Kesehatan, daerah di Indonesia dibagi atas daerah perkotaan, daerah pedesaan, daerah terpencil dan sngat terpencil. Ketentuan untuk masing-masing jenis daerah tersebut memiliki perbedaan, sebagaimana ketentuan mengenai kompensasi. Melalui perbedaan tersebut dapat dilihat bahwa pemerintah sepenuhnya menyadari perbedaan kondisi keidupan dalam lingkungan yang lebih luas pada berbagai jenis daerah tersebut. Apabila dapat memilih, dokter sebagai tenaga kesehatan pasti akan memilih daerah perkotaan yang lebih layak dan disukai sebagai tempat tinggal dengan askes transportasi dan komunikasi yang mudah diperoleh. Oleh karena itu, untuk meningatkan kesediaan dokter ditempatkan di daerah terpencil dan sangat terpencil maka pemerintah memberikan kompensasi yang berbeda.

Kabupaten Buol yang termasuk dalam daerah sangat terpencil. Kondisi lingkungan yang lebih luas bagi kehidupan dokter pasti lebih sulit karena keterbatasan sarana transpportasi, akses komunikasi, dan kondisi daerah yang sepi. Namun pemerintah sudah memberikan kompensasi yang telah disepakati oleh dokter tersebut untuk bekerja di daerah terpencil dan sangat terpencil. Pemerintah Daerah Kabupaten Buol melalui Dinas Kesehatan juga telah memberikan fasilitas rumah yang dekat dengan Puskesmas, meskipun ada beberapa dokter yang lebih memilih untuk tinggal di daerah kota agar memiliki akses komunikasi yang lebih baik. 


\section{KESIMPULAN}

Dinas Kesehatan Kabupaten Buol pada dasarnya sudah melaksanakan proses rekrutmen dengan baik melalui tahap perencanaan dengan analisis kebutuhan, pelaksanaan melalui sosialisasi dan pengelolaan aplikasi, pemilihan kandidat, kontrak atau perjanjian kerja, dan penggabungan dengan penempatan dokter di wilayah Puskesmas Kabupaten Buol. Penempatan dokter dutamakan dulu dengan mengisi kekosongan pada Puskesmas yang berlokasi jauh dari Rumah Sakit Rujukan. Permsalahan yang terjadi dalam rekrutmen adalah kurangnya jumlah pelamar. Hal ini dapat disebabkan karena kurangnya minat dan kesediaan dokter untuk bekerja di Kabupaten Buol.

Ada beberapa faktor yang mempegaruhi kesediaan dokter d untuk bekerja di Kabupaten Buol. Faktor yang mendukung kesediaan dokter untuk bekerja di Kabupaten Buol adalah kompensasi yang sudah sesuai dengan standar gaji untuk wilayah terpencil dan penghargaan serta jenjang karir dimana dokter masih memiliki peluang untuk menjadi PNS dan mendapatkan promosi pendidikan lebih lanjut. Fakto yang menghambat kesediaan dokter untuk bekerja di Kabupaten Buol adalah kondisi kerja yang dinilai sangat berat karena kurangnya jumlah dokter pada Puskesmas rawat inap dan Puskesmas non rawat inap di Kabupaten Buol serta faktor lingkungan yang lebih luas yang dirasa sepi dan terpencil dan menjadi hambatan bagi sebagian dokter.

\section{DAFTAR PUSTAKA}

1. AIPHSS. (2016, Juni 8). Building Block: Sumber Daya Manusia Kesehatan. Retrieved Desember 19, 2016, from Australia Indonesia Partnership for Health Systems Strenghtening: http://aiphss.org/id/sumber-daya-manusiakesehatan-apa-yang-masih-kurang/

2. Creswell, J. W. (2016). Research Design Pendekatan Metode Kualitatif, Kuantitaif, dan Campuran (4th ed.). Yogyakarta: Pustaka Pelajar.

3. Dessler, G. (2006). Manajemen Sumber Daya Manusia. New Jersey: Prentice Hall.

4. Gomes, F. C. (2011). Manajemen Sumber Daya Manusia. Yogyakarta: Andi.

5. Green, A. (2007). An Introduction to Health Planning for Developing Health Systems. New York: Oxford University Press.

6. Ivancevich, J. M., Konopaske, R., \& Matteson, M. T. (2011). Perilaku dan Manajemen Organisasi. Jakarta: Erlangga.
7. Kadam, S., Nallala, S., Zodpey, S., Pati, S., Hussain, M. A., Chauhan, A. S., et al. (2016). A Study of Organizational Versus Individual Needs Related to Recruitment, Deployment and Promotion of Doctors Working in the Government Health System in Odisha state, India. Human Resources for Health, 14-27.

8. Kurniati, A., \& Efendi, F. (2012). Manajemen Sumber Daya Manusia Kesehatan. Jakarta: Salemba Medika.

9. Ma, R., \& Allen, D. G. (2009). Recruiting Across Cultures: A Value-Based Model of Recruitment. Human Resource Management Review, Volume 19, Issue 4, December 2009, 334-346.

10. Mathis, R. L., Jackson, J. H., \& Valentine, S. R. (2014). Human Resource Management. Boston, MA: Cengage Learning.

11. Meliala, A. (2015). Kebijakan Distribusi dan Keterlekatan Dokter Spesialis di Indonesia. Yogyakarta: Fakultas Kedokteran Universitas Gadjah Mada.

12. Murthy, S., Rao, K., Ramani, S., Chokshi, M., Khandpur, N., \& Hazarika, I. (2012). What Do Doctors Want? Incentives to Increase Rural Recruitment and Retention in India . BMC Proceedings 2012, 6(Suppl 1):P5, 1-2.

13. Mustapha, A. M., Ilesanmi, O., \& Aremu, M. (2013). The Impacts of Well Planned Recruitment and Selection Process on Corporate Performance in Nigerian Banking Industry (A Case Study of First Bank Plc 2004-2011)". International Journal of Academic Research in Bussiness and School Sciences, 3, 633-648.

14. Nawawi, H., \& Hadari, H. M. (2000). Administrasi Personel untuk Peningkatan Produktivitas Kerja. Jakarta: Mesagung.

15. Niles, N. J. (2013). Basic Concepts of Health Care Human Resource Management. Burlington, MA: Jones \& Bartlett Learning.

16. Pankl, E., Theiss-White, D., \& Bushing, M. C. (2010). Recruitment, Development, and Retention of Information Professionals: Trends in Human Resources and Knowledge Management. New York: IGI Global.

17. Purohit, B., \& Martineau, T. (2016). Issues and Challenges in Recruitment for Government Doctors in Gujarat, India . Human Resources for Health (2016), 14-43.

18. Pynes, J. E. (2004). Human Resources Management for Public and Nonprofit Organizations. San Fracisco: Jossey-Bass.

19. Pynes, J. E., \& Lombardi, D. N. (2011). Human Resources Management for Health Care 
Organizations: A Strategic Approach. San Francisco, CA: John Willey \& Sons.

20. Richardson, M. A. (2007). Recruitment Strategies, Managing/Effecting The Recruitment Process. Working Paper.

21. Schuler, R. S., \& Jackson, S. E. (2008). Strategic Human Resources Management. New Delhi: Wiley India.

22. Sims, R. R. (2002). Organizational Success Through Effective Human Resources Management. London: Greenwood.

23. Steers, R. M. (2006). Organizational Effectiveness: A Behavioural View (Goodyear ed.). Jakarta: Geneva.
24. Stredwick, J. (2005). An Introduction to Human Resource Management. Oxford: Elsevier.

25. Wang, J., Su, J., Jia, M., \& Zeng, Z. (2013). What Interventions Do Rural Doctors Think Will Increase Recruitment in Rural Areas: A Survey of 2778 Health Workers in Beijing. Human Resources for Health 2013, 11-40.

26. Witter, S., Ha, B. T., Sengalia, B., \& Vujick, M. (2011). Understanding the 'Four Directions of Travel': Qualitative Research Into the Factors Affecting Recruitment and Retention of Doctors in Rural Vietnam. Human Resources for Health 2011, 9-20. 